\title{
Stopping the unstoppable? A discursive-institutionalist analysis of Renewable Transport Fuel Policy
}

Abstract From a discursive-institutionalist perspective, this paper seeks to establish the influence exerted over environmental agenda-setting and policy change by ideas and discourse, through an examination of recent developments in the UK's flagship biofuels policy, the Renewable Transport Fuels Obligation (RTFO). Discursive-institutionalism's central contention is that the intricate interactions between ideas and institutions should be at the centre of studies of the policymaking process. By elucidating the mutually reinforcing character of cognitive processes (including 'framing' and 'boundary work') and institutional factors (such as 'standard operating procedures' and path dependency), this paper shows how, despite a raft of countervailing evidence, significant changes in both the form and objectives of the RTFO were precluded. Longer-term research is required to establish the precise precipitating circumstances enabling such stability to result from these feedbacks however, as it is - theoretically at least - equally likely that far shorter periods of dramatic policy change, or "paradigm shifts", will result.

Key Words Discursive-Institutionalism, Agenda Setting, Policy Change, Biofuels

\section{Introduction}

In an era that has witnessed the emergence of climate change and energy security as major political issues in the UK, and indeed the convergence of climate change and energy agendas more broadly (Lovell et al., 2009), levels of greenhouse gas (GHG) emissions generated by private road transport have risen considerably ${ }^{1}$. Ostensibly carbon-neutral

\footnotetext{
${ }^{1}$ Carbon dioxide emissions from private car use in the UK rose by 13\% between 1990 and 2007 (DEFRA, 2009, page 21).
} 
biofuels, which are derived from biomass ${ }^{2}$ and can directly substitute for petrol and diesel without necessitating major alterations to existing vehicles or infrastructure (Anderson and Fergusson, 2006, page 180; IEA, 2004), have been heavily promoted as a solution to both of these problems. Moreover, they are seen by many as an effective stimulant for rural economic development in both the Global North and South. In view of all these alleged benefits, the EU passed a Biofuels Directive in 2003 (EC, 2003), which recommended that 10\% of all road transport fuel consumed in EU member states should be renewable by 2020. In October 2007, British policymakers responded to this Directive with the Renewable Transport Fuels Obligation (RTFO) (UK Government, 2007), which obliges fuel suppliers to blend a minimum proportion of biofuels into the petrol and diesel that they sell in the UK.

Despite the many alleged benefits of biofuels however, the RTFO was a highly controversial policy. By early 2008 calls in favour of abandoning or revising it had been articulated by, amongst others, numerous non-governmental organisations (NGOs) (see for instance Greenpeace, 2007; RPSB, 2008), the Royal Society (2008), and two of the Government's own Chief Scientific Advisers (The Times, 2008a; BBC News, 2008a). Such calls were underpinned, variously, by arguments stating that the fossil-fuel inputs needed to cultivate, process, and transport biofuels would render them unsustainable, and that biofuel production would exert negative impacts upon biodiversity, water and soil quality and quantity, food security, and even, in some specific locations, social welfare. Many also drew upon scientific research which indicated that, by inevitably driving direct or indirect land-use changes, biofuel cultivation might generate GHG emissions far in excess of any savings subsequently achieved by using the biofuels themselves (Fargione et al., 2008; Searchinger et al, 2008). In February 2008, the UK Government responded to this controversy by

\footnotetext{
${ }^{2}$ The majority of existing transport biofuels are derived from processed sugars or oils found in crops such as maize, sugar cane, oilseed rape, soy and palm oil.
} 
commissioning the Gallagher Review, an independent scientific review of the indirect effects' of biofuel production. When published in July 2008, this review called for a reduced rate of expansion in biofuel blending under the RTFO, to reach 5\% by 2013 instead of 2011.

The highly adversarial nature of this so-called 'biofuels debate', coupled with its temporal proximity to a change in policy, raises several interesting questions about the role of ideas and discourse in the environmental policymaking process. How, for instance, did political actors in this debate structure their arguments to render them authoritative and persuasive to decision-makers? How and why was scientific knowledge deployed in these arguments, and in what ways were relevant uncertainties and ambiguities interpreted and negotiated? Above all, how much influence did individual arguments actually exert over developments in the UK's biofuels policy, and why?

Such questions are at the heart of what Schmidt (2008) has labelled 'discursive institutionalism', an approach to analysing policymaking which takes the roles of ideas and discourse in generating policy changes seriously. This approach does not seek to demonstrate the superior status of ideas and discourse as the ultimate drivers of policy change, however. Rather, in recognising that these variables are always constructed and interpreted within a particular institutional context, it aims to establish precisely 'how, when, where and why ideas and discourse matter' in the policy process (Schmidt, 2008, page 305). This paper therefore seeks to conduct a discursive institutionalist analysis of developments in the RTFO by elucidating the intricate interplay of variables underlying the agenda setting and policy change processes, including not just scientific evidence and discursive argument but also political interests and institutional factors.

The remainder of the paper begins by providing a critical review of existing work on agenda setting and policy change, drawing from both interpretive policy analysis and Science 
and Technology Studies (STS) ${ }^{3}$. A series of theoretical frameworks and concepts compatible with Schmidt's (2008) 'discursive institutionalism' are then identified, before the paper's research design and methodology are briefly explicated and justified. Next, the agenda setting process which led to the RTFO, and the early stages of the debate, are discussed. Subsequently, the paper applies discursive-institutionalism to an assessment of the dynamics of the biofuels debate at its height in 2007-2008, before speculating on the role played by this debate in generating subsequent policy change as recommended by the Gallagher Review. Finally, a series of conclusions, both specific to this policy area and more broadly applicable to environmental policymaking as a whole, are advanced.

\section{Theorising the policy process - Identifying a 'discursive-institutionalist' toolkit}

To facilitate the identification of those areas of the wide, diverse, and sometimes confusing literatures on agenda setting and policy change that are compatible with discursiveinstitutionalism, the paper here follows Keeley and Scoones (1999) in subscribing to a typology which identifies three different, if slightly overlapping bodies of theory. Respectively, these approaches view policy outcomes as the product of: (1) bargaining and negotiation between competing interest groups; (2) the strategic mobilisation of knowledge and ideas by individual actors; and (3) policy discourses, which influence actors' perceptions of their own interests, and thus of policy problems themselves.

According to the first of Keeley and Scoones' approaches, we might conceive of the UK biofuels debate as pluralistic, and therefore view the RTFO as the exclusive result of competition between interest groups. Whilst pluralism has a long history however, many have

\footnotetext{
${ }^{3}$ These two literatures are rarely cross-fertilised, yet both have much to say about the relationship between cognitive variables and policymaking. Thus, interpretive policy analysis views the relationship between ideas and policy as but one component of a more complex, broader policymaking process, whilst STS aims instead to elucidate how science and technology, on both material and discursive levels, interact with the structure and governance of society itself.
} 
criticised its implicit view of the policy process as a cyclical series of stages (Lasswell, 1956; Figure 1), and also its one-dimensional account of power, which recognises only the overt manipulation of one actor by another (Dahl, 1957). More covert, strategic means of exercising power, such as 'non-decision making' (Bachrach and Baratz, 1962) and the 'mobilisation of bias' (Schattschneider, 1960), are consequently overlooked by this approach.

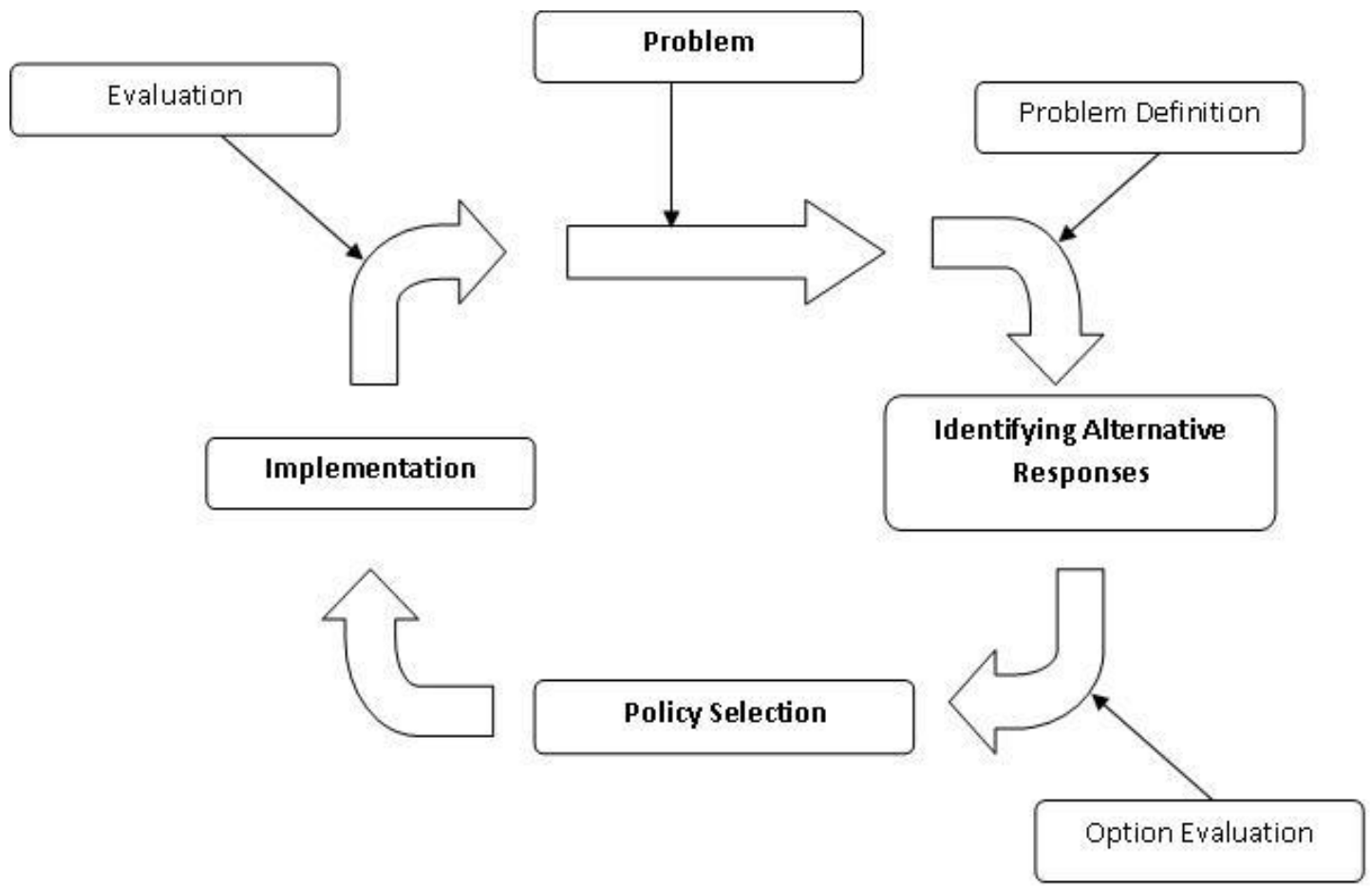

Figure 1: Diagram of the 'policy life cycle' (Source: Parsons, 1995, page 77).

Yet, despite these drawbacks, the influence of pluralism is clearly evident in a number of contemporary theories. For instance, under policy network analysis (Marsh and Rhodes, 1992), policies are ultimately determined by the precise nature and configuration of 'resource dependencies' (Benson, 1982, page 148) linking interest groups together. Such resource dependencies might comprise a particular industry's economic dependence upon state investment, or a policymaker's cognitive dependence upon independent expert institutions, for example. 


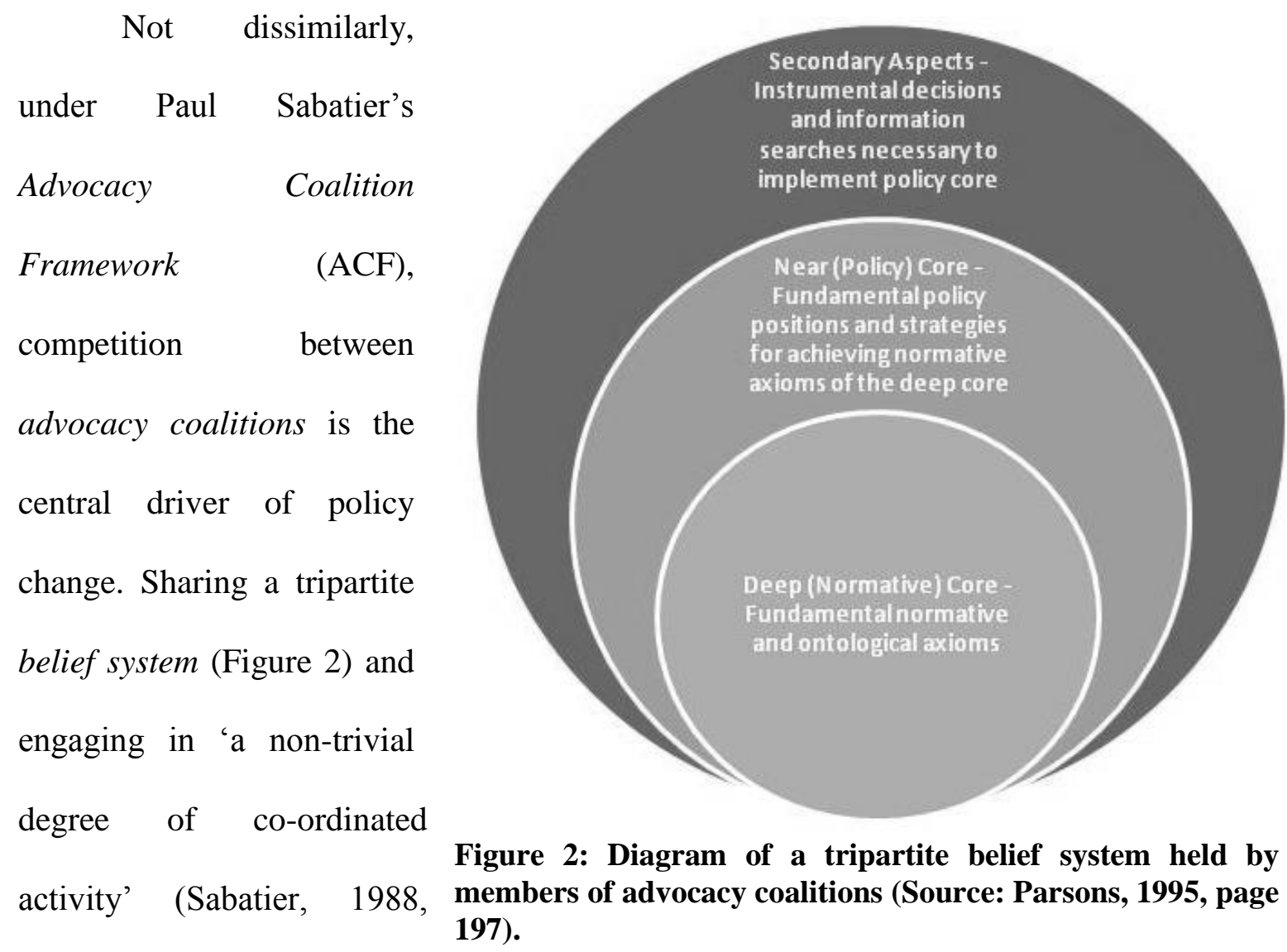

page 139), members of these

coalitions are additionally notable, however, in that they engage in "policy-oriented learning", which enables them to revise their beliefs in line with new knowledge. Sabatier thus imbues interest group competition with a distinctly argumentative dimension, as coalitions perpetually seek out new knowledge and evidence upon which to strengthen their claims and discredit those of others. Yet the political influence of knowledge and ideas ultimately remains limited under the ACF, because policy-oriented-learning can only induce changes in the more trivial, secondary components of a coalition's belief system ${ }^{4}$. Thus, even though revisions to the theory (Jenkins-Smith and Sabatier, 1993) have conceded that cognitive 'enlightenment' (Weiss, 1977) might drive changes in deeper beliefs over longer

\footnotetext{
${ }^{4}$ Revisions to more trenchant, 'policy core' beliefs primarily derive from non-cognitive processes, like 'external (system) events', whilst changes in deep, core beliefs are even less probable, supposedly 'akin to a religious conversion' (Sabatier, 1988, page 145).
} 
timescales, the theory has been criticised for conceiving of knowledge and ideas as subservient to political interests, which are themselves viewed as objective, trenchant entities.

By direct contrast, following work under the second bracket of Keeley and Scoones' (1999) typology, cognitive variables assume a far more independent role as drivers of policy change. As an excellent example, we might refer to the work of John Kingdon (2003), who draws upon Cohen, March and Olsen's (1972) 'garbage can model of organisational choice' to view policymaking as the combined activity of three 'process streams' - problems, policies and politics - that, whilst normally independent, will occasionally merge, thereby opening a 'policy window' and facilitating significant policy change. Under this framework, Kingdon accords special explanatory power to the activity of so-called policy entrepreneurs, who are said to facilitate the coupling of process streams by 'softening-up' the policy community to their ideas, and by pushing their "pet solutions" and preferred conceptions of particular problems 'at the propitious moments' (2003, page 205). In a similar vein, Baumgartner and Jones' (1991) theory of 'punctuated equilibrium' proposes that actors might try to strategically influence policy both by manipulating 'the prevailing image' of a problem, through the use of rhetoric and symbols, and by 'altering the roster of participants involved,' through the choice of a favourable "venue" within which to articulate their views (1991, page 1045). The sorts of strategic activity envisaged by these authors is significant both because it implies that policymaking is in fact a 'complexly interactive, non-linear' process (Lindblom and Woodhouse, 1993, page 11), and also because it hints at the presence of what Lukes (2005, page 28) has termed the 'third dimension of power', one which involves 'the shaping of perceptions, cognitions and preferences'.

Under the rationality of this second group of theories, political interests can thus be viewed, in line with the tenets of discursive institutionalism, as 'dynamic, dependent 
variable[s]' (Radaelli, 1995, page 165), open to revision on the basis of new knowledge and persuasive argument. In subscribing to a wider 'argumentative turn' in political science, which proffers that 'language does not simply mirror the world, [but] profoundly shapes our view of it in the first place' (Fischer and Forester, 1993, page 1), these theories therefore lead us to recognise that policy problems are not fixed, stable phenomena, but actually ideas in themselves, open to multiple, conflicting interpretations.

Particularly where "policymakers face "wicked" problems, complex influences, shifting commitments, and moral complexity' (Hajer and Laws, 2006, page 251), the potential influence of persuasion and rhetoric is very large. Sometimes this is because 'wicked problems' (Rittel and Webber, 1973) are "trans-scientific" (Weinberg, 1972); they entail questions that cannot be answered by objective scientific inquiry. On other occasions, more intractable 'incertitudes' may exist (Jasanoff, 1990; Stirling, 2003); for instance knowledge may be inhibited by indeterminacy ('where not all of the parameters of a system and its interactions are fully known') or even by simple ignorance ('where it is not known what is not known') (Shackley and Wynne, 1996, page 283; see also Wynne et al., 2007, page 36). For instance, knowledge of the impacts of indirect land-use change caused by biofuel production is constrained not just by Knightian uncertainty ${ }^{5}$ (Knight, 1921), but also by prevalent indeterminacies ${ }^{6}$. Crucially, wherever such incertitudes exist, any recourse to "the facts" will inevitably fail to identify the "correct" policy option, leaving a power vacuum

\footnotetext{
${ }^{5}$ Knightian uncertainty can be defined as 'randomness with unknowable probabilities' (Knight, 1921), and exists only where the full range of possible outcomes that might arise from a given situation are known (Stirling, 2003)

${ }^{6}$ In the words of a prominent bioenergy expert, these impacts are calculated by "modelling which is inherently non-specific, [which] doesn't tell you where the land-use changes are" (Interview, 26/06/09).
} 
whose capture almost invariably requires actors to persuasively mobilise knowledge, ideas and argument.

Drawing upon Science and Technology Studies (STS), we can identify 'boundary work', a process by which such persuasive, rhetorical argument is used to delineate the boundaries between science and politics, as one type of strategy that actors might use to capture power in the context of incertitudes. Whilst STS scholars such as Gieryn (1983) and Jasanoff (1990) have primarily shown how boundary work is used by scientists and technical experts to preserve their own cognitive authority in the face of "wicked problems", the strategy is by no means inaccessible to other actors in the policy process. Indeed, by advocating how best to achieve a separation of powers between science and politics in solving policy problems, boundary work can be used by any actor to promote certain courses of action over others, whilst simultaneously concealing the myriad ways in which science and politics are mutually intertwined. In this last respect, we might observe how 'boundarydefining terms' like 'risk assessment' and 'risk management' themselves influence the allocation of political power, such that their meaning 'cannot be established independently of the political process' (Jasanoff, 1987, page 226). Science and social order are therefore 'coproduced'; 'the ways we know and represent the world are inseparable from the ways we choose to live in it' (Jasanoff, 2004, page 2).

Unfortunately, whilst incertitudes today arguably pervade environmental policymaking more than ever, accounts of boundary work and co-production rarely feature in political scientists' work. Instead, following the third approach identified by Keeley and Scoones (1999), the manner in which incertitudes are negotiated can be more accurately captured by employing an interpretive set of conceptual tools whose aim is to elucidate how and why political actors 'allocate particular significance to specific social or physical events' 
over others (Hajer and Laws, 2006, page 252). Prominent amongst these tools is the concept of discourse, defined by Hajer (1995, page 44) as 'a specific ensemble of ideas, concepts and categorizations that are produced, reproduced and transformed in a particular set of practices and through which meaning is given to physical and social realities.' Following Foucault (1972; 1978), interpretive policy analysts argue that particular 'discursive formations' (ideas, concepts and categorisations) operate to 'determine what can and cannot be thought', governing the legitimate range of options for dealing with policy problems (Hajer and Versteeg, 2005, page 178). Importantly, discourse possesses both generative and repressive power; that is, it 'facilitates the production of identities and interests' (Litfin, 1994, page 29) even as it simultaneously suppresses and marginalises others.

In order to demonstrate the political influence of discourse, Hajer (1993) advances the concept of the 'narrative storyline', which is said to facilitate a 'communicative miracle' whereby actors from diverse backgrounds can relate to each other's accounts of a complex policy problem, albeit without understanding each other perfectly. By reducing the complexities of a given problem to 'a catchy one-liner' (Hajer, 1995, page 62), narrative storylines 'reconstruct common sense to make the contingent seem determined and the artificial seem natural' (Cronon, 1992, page 1349). Not dissimilarly, other interpretive scholars have highlighted the influence of 'frames', which operate as 'special types of story that...provide stability and structure by narrating a problem-centred discourse...over time' (Laws and Rein, 2003, page 174). Crucially, whilst dominant storylines and frames often operate to constrain policy, by reifying particular accounts of a problem, their innate simplicity also leaves them vulnerable to attack, particularly where actors are able to find empirical evidence that undermines them. As a result, the ability to create or modify a 
persuasive storyline about biofuels, or to '(re)frame' the biofuels debate itself (Rein and Schön, 1991), is seen by interpretive policy analysts as a source of great political power.

Yet, as Hajer and Laws (2006, page 261) themselves point out, whether 'reframing' will actually yield power depends heavily upon 'how others respond to [a narrative], twist it, [and] take it up.' Indeed, whilst some accounts of biofuels might struggle to gain political influence for want of a favourable institutional "venue" for their articulation, others, given the right conditions, might actually become institutions in their own right. Such a view of institutions, as both structures and constructs, is another key characteristic of discursive institutionalism, and provides political scientists with an invaluable indication of the interactions of agency and structure in the policymaking process (Giddens, 1990). In short, 'rational argument, the presentation of evidence and the process of persuasion are...bounded by institutional limits' (O'Riordan and Jordan, 1996). As a result, under discursive institutionalism, it would be 'inappropriate' to formulate explanations of changes in UK biofuels policy that posit 'the wholesale replacement of interests...with the power of persuasion and meaning' (Bulkeley, 2000, page 735).

A particularly instructive example of how discursive institutionalism has been applied elsewhere can be found in the work of Peter Hall (1993). In a seminal paper, Hall advances a typology of policy changes running from first-order shifts in the targets and thresholds of a particular policy instrument, through second-order changes in the nature of that instrument itself, and finally on to third-order changes, or 'paradigm shifts' (Kuhn, 1962), in which the underlying aims and objectives of policy are openly questioned and revised. Drawing on his assessment of the drivers of historical changes in British economic policy, Hall concludes that ideas and institutions will often 'reinforce each other', producing 'long periods of continuity' (1993, page 291) characterised by only first- or second-order policy changes. 
However, ideas are also said by Hall to possess a 'status somewhat independent of institutions that can be used' to initiate paradigm shifts and bring about 'third-order' change (1993, page 290).

On this basis we might argue that the key questions policy scientists should be addressing in their work are 'how, when, where and why' do ideas and discourse matter in the policy process? Yet, as Hall himself laments, the role played by these cognitive variables in policymaking, whilst critical in initiating third-order change, 'has proven especially difficult to model' (Hall, 1993, page 289). Indeed, in the words of Kingdon, we must ultimately acknowledge that whilst public policymaking 'does have a sort of structure,' there is also 'plenty of room for complexity, uncertainty, fluidity, and residual randomness' (Kingdon 2002, page 97). Consequently, in this paper, the case of the RTFO and the UK biofuels debate will be employed as 'a heuristic device for exploring possible conjunctions' (Litfin, 1994, page 7) between empirical evidence and a range of analytical concepts and frameworks compatible with discursive institutionalism, including boundary work, discourse, storylines, frames and the activity of policy entrepreneurs.

\section{Approaching the biofuels debate - Methodology}

The empirical data presented here is drawn from numerous sources, primarily comprising semi-structured interviews and documentary evidence. Eight interviews were conducted with individuals from industry, expert and non-governmental organisation backgrounds, whose views were collectively representative of those circulating in the wider biofuels debate. Critically, these respondents were also able, by virtue of their positions, to act as 'knowledgeable informants...about the perspectives of people in the key locations' (Kingdon, 2003, page 233) with respect to decision-making itself. Accounts of policymakers' views were also derived from an analysis of documentary sources directly attributable to key 
Governmental actors and institutions. Much of the remaining data comprises evidence submitted by a range of actors, including policymakers, to the Parliamentary Environmental Audit Committee, in preparation for its report 'Are Biofuels Sustainable?' (EAC, 2008a). These submissions are useful both because they contain well-prepared and carefully thoughtthrough arguments, and because they control for the possibility that an argument might have derived influence from the idiosyncrasies of the institutional venue within which it was deployed. Finally, in order to contextualise the analysis, press releases, newspaper articles, speech transcripts and scientific reports, including the Gallagher Review, were analysed in detail.

\section{Agenda setting and early policy developments, 2003-2006}

Perhaps unsurprisingly, interview respondents unanimously agreed that the RTFO was driven at least partly by political events in Europe, and in particular by the lobbying of the agricultural sector. Thus, one interviewee, formerly of the Royal Society for the Protection of Birds (RSPB), claimed that farmers 'had a complete stranglehold over Brussels' (Interview, 08/07/09), whilst a prominent bioenergy expert described the motives underlying the EU's Biofuels Directive (EC, 2003) as 'nakedly obvious'; it was 'a way of subsidising agricultural activities and getting around the Common Agricultural Policy' (Interview, 26/06/09).

Not all interviewees were convinced that European developments alone could explain the introduction of the RTFO, however. For instance, a senior official at Friends of the Earth Scotland attributed the decision to implement a biofuels mandate to the influence of the electricity sector's Renewables Obligation (UK Government, 2002), which policymakers had probably viewed as 'a tried and tested, British way of doing things' (Interview, 29/06/09). This claim suggests that policy formulation on biofuels was to some extent path dependent, 
since 'the impact of the institutional history' of UK renewable energy policy was high (Kirk et al., 2007, page 250). It also evokes Allison's (1971) concept of 'standard operating procedures', which help to 'reassure' civil servants confronted with novel or uncharted policy problems (Heclo, 1974, page 315).

At a more abstract level, one prominent academic, in contending that biofuels were 'a solution to a [problem other than climate change] looking for a justification' (Interview, 26/06/09), evoked Kingdon's (2003) concept of the policy entrepreneur by suggesting that some groups had strategically depicted biofuels - their own "pet solution" to the problem of peak oil in road transport - as a tool for mitigating climate change. In thus linking biofuels to what one Environment Agency policy officer identified as a general 'feeling that something had to be done [to reduce GHG emissions from] the transport sector' (Interview, 08/07/09), these entrepreneurs successfully prised open a policy window, through which the RTFO could subsequently pass.

Notably, policymakers' concomitant framing of biofuels as a climate-change mitigation tool did not immediately prove to be controversial; many NGOs initially encouraged a domestic biofuels mandate to complement the EU's Biofuels Directive (The Guardian, 2004; British Sugar, 2005). Some interviewees attributed this paradox to the absence of detailed knowledge about the actual impacts of biofuel production, with one Environment Agency official even labelling controversy over biofuels prior to 2005 as 'lots of people shouting at each another in a very uninformed way' (Interview, 08/07/09). In a bid to eradicate this ignorance, bodies such as the Institute for European Environmental Policy (IEEP) and the European Commission's Joint Research Centre began, from 2004, to produce independent reports on the impacts of biofuels (Bauen et al., 2004; EUCAR, CONCAWE and JRC, 2004), targeted primarily at policymakers. Yet, according to a co-author of one such 
report, they 'made not a blind bit of difference to the outcome' (Interview, 08/07/09), serving primarily instead to alert environmental NGOs to the potentially deleterious impacts of the RTFO. As a former RSPB campaigner explained:

'The evidence changed quite a lot...we began to get a much better understanding of the impacts. Those all entered the consciousness of NGOs...and it was looking increasingly dodgy' (Interview, 08/07/09).

Two important conclusions can be drawn from this brief discussion. Firstly, no single factor can account for the RTFO's inception; numerous processes, both cognitive and institutional, combined to enhance its legitimacy and to set the political agenda. Secondly, since important advances in knowledge about the potential impacts of biofuels occurred only after the RTFO had been proposed, this knowledge struggled to exert any direct influence over the policy's subsequent development.

\section{Conceptualising the UK 'Biofuels Debate', 2007-2008}

By the time of its passing into law in October 2007, the UK's Renewable Transport Fuel Obligation had become the subject of intense public controversy. In the ensuing debate, strong and compelling arguments in favour of immediately implementing the policy clashed with equally convincing calls for a moratorium on biofuels, at least until more was known about their potential impacts. This section seeks to elucidate the main dimensions of this 'biofuels debate', which displayed all the characteristics typical of a 'dialogue of the deaf' (van Eeten, 1999), by interpreting both primary and secondary data through the lens of discursive-institutionalism, and in particular by applying the concepts of discourse, storylines, frames and boundary work.

Discourse and storylines 
Jointly comprising one side of the biofuels debate, the biofuels industry, fossil fuel suppliers, vehicle manufacturers and the bio-scientific research community all combined to lend their joint support to the RTFO, albeit for quite different reasons. Thus, whilst fossil fuel suppliers and vehicle manufacturers, in the eyes of a prominent Friends of the Earth Scotland official, supported the policy on the basis that it would help to 'lock in the current models of mobility through fossil fuel vehicles' (Interview, 29/06/09), the biofuels industry, in line with a wider research community of bio-technologists and environmental scientists, saw the RTFO as a stepping stone towards a purported 'bio-economy', within which society would eventually depend for all of its energy, industrial and food requirements upon land. Taken together, these groups can be thought of as the RTFO's advocates.

Calling for the immediate implementation of the RTFO, many of these groups sought to draw attention to the potential advantages of so-called "advanced" biofuels, as when General Motors UK and Ireland contended that 'greater support for research into the development of [advanced feedstocks]...would help to enhance the sustainability of biofuels for the longer term' (Ev-1647). Similarly, British Petroleum argued that 'support for biofuels should not be based solely on their current potential, but also on...accelerating the development of advanced technologies' (Ev-195). At the same time, many advocates also openly supported proposals for carbon and sustainability standards under the RTFO, but only on the condition that these standards were realistic and achievable. Thus, the Low Carbon Vehicles Partnership (LCVP) called for an initial "reporting stage" that would give biofuel suppliers time 'to develop information flows through their supply chains' (Ev-74).

\footnotetext{
${ }^{7}$ Quotes derived from evidence submissions to the House of Commons Environmental Audit Committee are referenced in the format "Ev-xx", where $\mathrm{xx}$ denotes their page number in the Committee's published evidence document (EAC, 2008b).
} 
Unsurprisingly, these arguments themselves rested on the contention that strict, mandatory standards would 'stymie the growth of the industry' (National Farmers' Union, Ev-67).

Comprising the other side of the debate, by contrast, numerous environmental NGOs and a range of independent expert institutions all argued against the immediate implementation of the RTFO. According to the director of a national research programme investigating rural economy and land-use, these groups were united by their broad determination to question '[the extent to which] renewable energy and renewable resources should...take priority over other sorts of environmental concerns, like landscape and biodiversity' (Interview, 09/06/09). In view of the potentially negative impacts of biofuel production, these groups therefore argued that mandatory carbon and sustainability standards 'should be introduced urgently' under the RTFO (Greenpeace et al., 2008).

Like the advocates, critics deployed a wide array of claims to justify their stance on the RTFO. Thus, whilst many chose to emphasise the potential loss of biodiversity and pristine habitat that a rising demand for biofuel feedstocks like palm oil and soy would cause, particularly in the tropics ${ }^{8}$, others instead highlighted that potentially significant quantities of GHG emissions might be generated by land-use change. Indeed, this latter issue even led the Environmental Audit Committee to describe the RTFO as 'reckless' (EAC, 2008a, page 32). In addition, still other critics flagged up the potentially negative impact biofuels would have on food security, often employing the dramatic terms of Jean Ziegler, a UN special rapporteur on the Right to Food, who had in October 2007 branded biofuel production 'a crime against humanity' (BBC News, 2007). In a distinctly Malthusian vein, the majority of these groups also dismissed the contention that so-called "advanced" biofuels could ever resolve these

\footnotetext{
${ }^{8}$ This emphasis is clearly evident, for instance, in a joint-NGO campaign slogan: 'choose the right biofuel or the orang-utan gets it' (Greenpeace, 2007).
} 
problems, since, in the words of Greenpeace $U K$, these technologies 'do not conjure up new land' (Ev-159).

Two broad discourse coalitions (Hajer, 1993; Mander, 2008; Stevenson, 2009), arguing for and against the immediate implementation of the RTFO respectively, can thus be said to have driven the biofuels debate in this period. The first coalition subscribed to a discourse of ecological modernisation, and coalesced around a narrative storyline which constructed the RTFO as a sound policy that, if given time and managed appropriately, would be capable of both tackling climate change and boosting the British economy. By contrast, the second coalition subscribed to a broader discourse of sustainability and precaution, and coalesced around a much vaguer storyline, which constructed the RTFO as a potentially damaging and ill thought-through policy in several different respects.

\section{Framing}

These two discourse coalitions also differed from one another in terms of the implicit framings they adopted, both of the problem supposedly being tackled by the RTFO, and indeed of biofuels themselves.

In terms of the problem, advocates clearly framed GHG emissions emerging from the transport sector as somehow more important than emissions being generated elsewhere. As Merlin Hyman, Director of the Environmental Industries Commission, explained: 'Carbon emissions from transport are a key challenge. We do not have a great deal to offer in terms of reducing emissions in that sector' (Ev-24). At a deeper level, this view was itself underpinned by a 'meta-cultural framing' (Schön and Rein, 1994) which constructed existing patterns and levels of road transport use immutable, and which thus overlooked the possibility of reducing 
emissions through behavioural change or demand reduction ${ }^{9}$. Ultimately, this framing therefore depicted biofuels as the only option for cleaning up the road transport sector, and as essential to the UK's climate change mitigation efforts.

By direct contrast, critics of the RTFO framed transport sector emissions no differently to other GHG emissions, and depicted biofuels as just one of a large number of measures, including 'mandatory fuel efficiency standards, road pricing and speed control measures' (Environment Agency, Ev-61), available to British policymakers. Moreover, prevailing patterns and levels of transport use, far from being seen as immutable, were explicitly called into question, as when the Royal Society advocated 'an integrated approach, [combining] biofuels with...more specific policies to reduce demand and encourage behavioural change' (Royal Society, 2008, page 3). Moreover, having thus dispelled the myth that biofuels were 'essential' to the UK's climate change mitigation efforts, this framing was able to advocate the more efficient and cost-effective use of biomass as a climate change mitigation tool in the heating and electricity sectors.

\section{Boundary work}

Finally, advocates and critics of the RTFO also conducted boundary work (Gieryn, 1983) in the biofuels debate, which enabled them both to draw upon science as a 'source of authority', even as they advanced very different interpretations of that science, and its associated uncertainties (Dickson and Adams, 2009, page 110). For instance, in their calls for a carbon and sustainability "reporting period" under the RTFO, advocates implicitly contended that scientific knowledge pertaining to the impacts of biofuel production would inevitably improve as the policy matured. They thus cast the impacts of biofuel production as

\footnotetext{
${ }^{9}$ Biofuels Corporation Ltd. even praised the RTFO on the very basis that it 'does not rely on changing
} individual behaviour' (Ev-1). 
novel problems for scientists to successively explore, document, and bring under control, as when a senior official at Royal Dutch Shell asserted that discussions of indirect land-use change needed 'to move on from rhetoric into good scientific-based conversation' (Interview, 30/6/09). Critically, this boundary work enabled advocates such as Lord Browne of Madingley, former Chief Executive of BP, to construct scientific uncertainties as an insufficient basis for withdrawing support from the biofuels industry:

"Don't let policy get ahead of science. An example is the indirect impact of growing biofuels on GHG emissions due to knock-on changes in land-use. While this is important, it is not sufficiently well understood to be the basis of sweeping policy changes" (The Times, 2008b).

Critics, by contrast, adopted different stances on the implications of scientific uncertainties for policy. For instance, some actually aligned themselves with advocates in implicitly asserting that scientific knowledge would improve with time, as when Friends of the Earth lamented that 'the rush to convert to biofuels is happening without all the data about the impacts...being available' (Ev-29). Others, by contrast, chose to depict scientific uncertainties, and in particular those surrounding the impacts of indirect land-use change, as inherently irresolvable. In so doing, these critics explicitly sought to draw policymakers' attention to the existence of quite intractable ambiguities and indeterminacies regarding the impacts of biofuel production, and thus called into question the assumption that knowledge of these problems would eventually improve sufficiently to resolve political controversy.

In addition, both advocates and critics of the RTFO also sought to enhance the persuasiveness of their arguments by engaging in boundary work on a more confrontational level, in which they contrasted their own, supposedly apolitical views with those of their competitors. Thus, whilst Greenpeace $U K$ described the biofuels industry as 'politically 
created' (Ev-159) and Friends of the Earth urged policymakers 'to be aware of where the drive for biofuels is coming from' (Ev-46), the Renewable Energy Association denounced critics' claims as 'ill-informed and misleading' (Ev-9).

\section{Explaining policy change - A discursive institutionalist view}

On the surface, the discourse used by policymakers when discussing the RTFO in the period preceding the publication of the Gallagher Review shared much in common with the eco-modernist stance subscribed to by advocates of the policy. Thus, in giving evidence to the Environmental Audit Committee, Transport Minister Jim Fitzpatrick took the view that '[without] first generation biofuels we will not get to second generation biofuels' (Ev-119), and also argued that the RTFO would provide an 'opportunity to collect data which will help pave the way toward...mandatory sustainability standards' (Fitzpatrick, 2008). Even more tellingly, the Minister also remarked of advanced biofuels that 'this sphere is very much part of the future global economy and we want to make sure we are part of that' (Ev-119).

On this evidence, we might conclude simply that the RTFO's advocates had successfully transplanted their eco-modernist discourse, characterised by a storyline emphasising patience and appropriate regulation, into policymakers' consciousness and vocabularies. Yet the discursive affinity between policymakers and the advocates might also be explained by institutional factors, and in particular by an economic interdependence linking the biofuels industry and the policymaking community, in which the former depended upon significant public sector investment and the latter viewed the development of "advanced" biofuels as critical to Britain's future economic competitiveness. However, as Hajer (1995, page 58) points out, 'even money power assumes some sort of discursive interchange', and consequently these institutional factors had to be consistently reasserted throughout the debate, as when a senior official from Royal Dutch Shell warned that 'the US 
will spend an absolute fortune in this [industry] over the next decade,' before suggesting that the UK should not 'let this one pass us by' (Interview, 30/06/09). As a result, it is probably appropriate to attribute the similarities between the advocates and policymakers' arguments to the mutually reinforcing influence of ideas and institutions, rather than one or other of these variables acting alone.

By contrast, arguments made by critics of the RTFO appear, at first glance, to have exerted very little impact upon policymakers' views prior to the commissioning of the Gallagher Review. In line with one Environment Agency official, who argued that these groups weren't '[very] market literate, and probably weren't very effective at arguing against the commercial interests' (Interview, 08/07/09), we might attribute this fact to the limited political appeal, and indeed clarity, of the critics' discourse, which emphasised the rather ambiguous tenets of sustainability and precaution, when compared with the advocates' ecomodernist stance.

Owing to the superior appeal of their eco-modernist discourse, advocates of the RTFO were thus able to set the terms of the biofuels debate in this period, which they did primarily by advancing the framings of biofuels and transport sector GHG emissions detailed earlier. In promoting these framings, these groups might even be said to have engaged in the sort of strategic action envisaged by Baumgartner and Jones (1991), both by (a) manipulating the 'image' of the problem being faced so as to depict road transport emissions as particularly entrenched and difficult to reduce, and (b) ensuring that the 'venue' within which the RTFO was discussed excluded any consideration of alternative uses of biomass, for instance in the heating and electricity sectors. Critics of the RTFO were consequently left with the tough task of trying to 'redefine and reframe' the debate (Mol, 2010, page 73), which they sought to achieve primarily by drawing attention to the more efficient use that might be made of 
biomass as a climate change mitigation tool in other sectors. As one prominent bioenergy expert explained in interview, to focus solely on transport emissions was, for the critics, to ask 'the wrong question' (Interview, 26/06/09). Yet, despite their best efforts and, incredibly, the rhetorical support of an official Government document published just months earlier (DTI, DfT and DEFRA, 2007), critics' attempts to reframe the debate in this way ultimately met with failure, as was lamented by Prof. Roland Clift (Ev-104):

'What the world needs far more than technologies to turn solid biofuels into liquids would be a reliable, small scale combined heat and power process... albeit it is lower technology and therefore does not attract the capital and engineering interest which it merits.'

Paradoxically, whilst critics exerted very little influence over the arguments used by policymakers to legitimise the RTFO in the months immediately following its passing into law, they did contribute significantly to the Government's eventual decision to commission the Gallagher Review. At an institutional level, the critics' influence over this decision might be effectively attributed to policymakers' knowledge ${ }^{10}$ that 'the best-known NGOs enjoy far higher levels of public trust than do their business counterparts' (Giddens, 2009, page 119), and are therefore able to exercise what Mol (2010, page 73) refers to as 'moral environmental authority'. As a result, when NGOs began, in the words of a former RSPB official, to wield their public campaigns against the RTFO 'as a threat to Government, as a way of really putting them on the spot' (Interview, 08/07/09), we might justifiably conclude that policymakers acted to prevent a potential collapse in public confidence by meeting those NGOs' concerns at least in spirit, and commissioning a review. More pragmatically, in the

\footnotetext{
${ }^{10}$ Jim Fitzpatrick, for instance, justified the Government's reluctance to force fuel suppliers to label biofuels which had been derived from sustainable sources by claiming that environmental NGOS could instead be relied upon 'to scrutinise very closely what individual [biofuel] suppliers are doing... and draw that to the attention of motorists' (Ev-114).
} 
words of one Environment Agency official, we might say that the impact of NGOs' campaigns, when combined with the publication of two high-profile reports on the impacts of biofuels (EAC, 2008; Royal Society, 2008) and the testimony of two Chief Scientific Advisers (The Times, 2008a; BBC News, 2008a; see also Dunlop, 2010), had in any case led the evidence against biofuels to reach 'such a pitch and such a degree of hysteria that [policymakers] could hardly not have responded in some way' (Interview, 08/07/09).

Whatever the precise cause of the Gallagher Review's inception, the document itself actually deployed terms and rhetoric that sat very comfortably with the discourse of sustainability and precaution subscribed to by critics of the RTFO. Thus, the review's authors echoed many of these groups in stating that 'any biofuel target could lead to a net increase in GHG emissions' (RFA, 2008, page 15). Moreover, in going on to contend that calculations of the impacts of indirect land-use change would 'require subjective assumptions and contain considerable uncertainty' (ibid, page 46), the Gallagher Review also aligned itself with those critics who had used boundary work to argue that this problem in particular was beset by incertitudes, and therefore inherently irresolvable.

Ultimately however, as a former RSPB campaigner lamented (Interview, 08/07/09), the Gallagher Review's tone was 'completely contradicted' by its policy recommendations, which comprised a call to reduce the Government's targets for biofuel blending and amounted only to "first-order" policy change. In attempting to account for this inconsistency, two Environment Agency officials contended that the review's recommendations had ultimately been constrained by the Government's inability to withdraw support from a biofuels industry that had become heavily institutionally embedded (Interview, 08/07/09). Indeed, whilst the downscaling called for might appear on the surface to have constituted a first step towards withdrawing state support for biofuels, in actual fact it provided reassurance 
to the industry of its long-term future, by extending the policy's lifespan by two years to 2013. At another level, recommendations for more significant changes were also probably precluded, according to many interviewees, by policymakers' knowledge that any attempt to implement the mandatory carbon and sustainability standards called for by critics would have been deemed a barrier to free trade between developing and developed countries by the World Trade Organisation (WTO) (Interview, 08/07/09).

Owing to these institutional factors, and despite having exerted a major influence over the Gallagher Review's description of the various problems associated with biofuels, critics therefore failed to influence changes in the actual form of the RTFO in any significant way. Whilst the Gallagher Review therefore marks the point in the biofuels debate at which critics achieved 'discourse structuration' (policymakers were subsequently obliged to draw upon their ideas, concepts and categorisations in order to mount a credible argument), as yet this group has ultimately failed to achieve 'discourse institutionalisation'"11 (those ideas, concepts and categorisations have not been translated into political reality) (Hajer, 1995, pages 61-62). This scenario did not particularly surprise one former RSPB campaigner, however, who remarked that 'reviews are ultimately ways to delay policy decisions' (Interview, 08/07/09). Accordingly, since the Review's publication, biofuels have slipped down the political and public agendas in the UK, in spite of recent projections (DECC, 2009, page 200) of an exponential increase in their usage, in line with new EU-level targets (EC, 2009).

\footnotetext{
${ }^{11}$ This term is distinct from and should not be confused with discursive institutionalism, the broad analytical approach adopted by the paper.
} 


\section{Conclusions}

"If [the Gallagher Review] shows that we need to change our approach, we will also push for change in EU biofuels targets" - Prime Minister Gordon Brown (BBC News, 2008b).

"Decisions on both targets and measures to ensure sustainability ultimately require political judgements" - The Gallagher Review (RFA, 2008).

Combining insights from the interpretive policy analysis and Science and Technology Studies, this paper has analysed the drivers of agenda setting and policy change by examining recent developments in the UK's Renewable Transport Fuels Obligation (RTFO), from a discursive-institutionalist perspective. A number of conclusions emerge from the analysis presented, both specific to this policy arena, and more generically relevant to the environmental policymaking process as a whole.

Beginning at a specific level, whilst all actors in the biofuels debate sought to render their arguments persuasive by subscribing to narrative storylines, which acted to condense often complex points into 'catchy one-liners' that 'sounded right' (Hajer, 1995, page 62), institutional circumstances were always pivotal in mediating these arguments' observed political influence. Thus, owing to the biofuel industry's position as an institution with the potential to contribute significantly to Britain's future economic growth, it was ultimately advocates of the RTFO that were able to set the terms of the biofuels debate in late 2007. By contrast, critics were forced to try and reframe the debate so as to encompass a wider range of policy options, and were to some extent held back by the intrinsic ambiguity of their own discourse of sustainability and precaution. Nonetheless, and owing to NGOs' perceived role as brokers of public trust in the policymaking community, they did contribute significantly to the Government's eventual decision to commission the Gallagher Review. Such findings 
clearly add legitimacy to the paper's discursive institutionalist stance, with its emphasis on the inherent interdependence of ideas and institutions as key variables in the policy process.

At another level, coherent boundary work, in which the problems associated with biofuel production were cast as purely scientific, was also clearly important in enabling the RTFO's advocates to set the terms of the biofuels debate. By contrast, critics were once again held back by a lack of clarity in this regard, choosing on some occasions to call for more robust scientific evidence, and on others to highlight the intractable ambiguities and indeterminacies surrounding particularly problematic issues such as indirect land-use change. Whilst these latter views certainly sit comfortably with work in STS questioning the existence of a definite boundary between science and politics (Jasanoff, 1990), it was ultimately the advocates' construction of a policy process informed by sound and objective scientific knowledge that won greater support in the corridors of Whitehall. The political appeal of such a 'technical-rational' link between scientific expertise and environmental policymaking thus remained high in this case, even as the rationale for such a relationship is increasingly being called into question in the social sciences (Fischer, 2009; Keller, 2009).

Finally, institutional factors were also shown to be vitally important in operating to preclude 'third-order' policy change (Hall, 1993) in this case. Thus, the agenda setting process which gave rise to the RTFO effectively acted to normalise investment of the UK's biomass resources in the production of liquid transport biofuels, by galvanising a previously embryonic biofuels industry. At the same time, WTO trade rules served as an institutional barrier to the implementation of some of the critics' policy recommendations. Consequently, policymakers were unable to retrace their steps when scientific knowledge and evidence calling the RTFO's presumed benefits into question did begin to accumulate. 
In order to identify the implications this case study has for broader academic understandings of environmental policymaking, it is of course necessary to revisit to the key question posed at the outset of the paper - precisely what role do ideas and discourse play in mediating the critical processes of agenda setting and policy change? In the first instance, the analysis presented here has demonstrated that such cognitive variables can influence policy in a far from trivial manner. The boundaries and biases of political agendas are evidently susceptible to clever argumentation, as when certain groups of political actors constructed transport biofuels as a solution to the problem of climate change. Likewise, perceptions of existing policies can be either changed or maintained through the strategic marshalling of scientific evidence and argument, couched within a compelling discourse, as was demonstrated by advocates of the RTFO in their decision to emphasise the potential economic benefits of a burgeoning biofuels industry, using strongly eco-modernist terms.

Despite this however, the analysis also shows that changes in the actual form of policy were not driven by ideas and discourse alone. This suggests that for scholars of policymaking to view such cognitive variables as an explanatory panacea would be both simplistic and counterproductive. Instead, the analysis indicates that it is the complex interactions between, and indeed the interdependence of, ideas and institutions, that must ultimately be evoked if genuinely robust explanations of policy change are to be formulated. In the specific case presented here, dominant ideas and existing institutions interacted in a self-reinforcing manner, thus acting to preclude major changes in the RTFO. According to Hall (1993, page 290), this should not be surprising, since 'the routines of policymaking are usually designed to reflect a particular set of ideas about what can and should be done in a sphere of policy.' In the words of a prominent bioenergy expert, this might legitimately be interpreted as evidence both that 'once a policy has got its own momentum up, it's very difficult to stop it', and 
indeed that 'once a policy's started down a stupid track ${ }^{12}$, it's very difficult to move it ${ }^{13}$, (Interview, 26/06/09). We might justifiably conclude, therefore, that significant degrees of momentum and path-dependence are intrinsic to environmental policymaking, and that 'it is the impact of previous policy itself that is probably the most pervasive manifestation of political learning' (Heclo, 1974, page 315).

Despite this conclusion's intuitive appeal however, because it is drawn from a case study of policy developments that spans only a few years, we would probably be well advised to apply it with caution. Indeed, referring back to the work of Hall (1993) once again, whose assessment of economic policy spanned several decades, we find that 'long periods of continuity' can in fact be 'punctuated occasionally by the disjunctive experience of paradigm shift' (ibid, page 291). As such, this suggests that a self-reinforcing relationship between ideas and institutions, for all its apparent stability, might actually be intrinsically volatile, and retain the capability to precipitate dramatic policy shifts in quite short periods of time. With this distinct possibility in mind the paper closes by calling for more concerted efforts to analyse in depth, and over longer time periods, the complex and intricate interactions between cognitive and institutional variables in a range of policy settings, in a bid to establish with greater certainty the sorts of circumstances under which either continued periods of stability or indeed dramatic "paradigm shifts" are likely to emerge. To be sure, such enquiries will be highly unlikely to yield law-like generalisations that apply in all policy issue-areas, but by adhering to the nuanced analytical stance of discursive-institutionalism that has been

\footnotetext{
${ }^{12}$ Notably, this claim evokes Heclo's (1974, page 312) contention that 'sheer stupidity' is a factor in the policy process 'unduly neglected' by many scholars.

${ }^{13}$ Such path-dependency was perhaps nowhere better exhibited in this setting than in the bio-scientific research community, where, according to two separate interviewees, the legitimacy of a drive for "sustainable" biofuels was never called into question, but instead naïvely constructed as 'a terrifically exciting scientific and technological challenge' (Interviews, 09/06/09; 26/06/09).
} 
firmly explicated here, they will at least enable scholars of policymaking to move away from one-dimensional, simplistic accounts that unproductively seek to locate political power exclusively in either the cognitive or the institutional domain.

\section{References:}

Allison G T, 1971 Essence of Decision: Explaining the Cuban Missile Crisis (Little Brown, Boston, MA)

Anderson G Q A, Fergusson M J, 2006, "Energy from biomass in the UK: sources, processes and biodiversity implications" Ibis 148 180-183

Bachrach P, Baratz M S, 1962, "Two Faces of Power" The American Political Science Review 56(4) 947-952

Bauen A, Eyre N, Fergusson M, Foley J, Hart D, Martin D, Mortimer N, Skea J, Vietch A, 2004, "Expert Paper on the Global Impacts of Road Transport Biofuels: A Contribution to the Government's Analysis", Cleaner Transport Forum, Institute for European Environmental Policy and National Society for Clean Air and Environmental Protection

Baumgartner F R, Jones B D, 1991, "Agenda Dynamics and Policy Subsystems" The Journal of Politics 53(4) 1044-1074

Benson J K, 1982, "A Framework for Policy Analysis", in Interorganizational Coordination: Theory, Research, and Implementation Eds D L Rogers, D A Whetten (Iowa State University Press, Ames, IA) pp 137-170

BBC News 2007, "Biofuels 'crime against humanity'", 27th October, http://news.bbc.co.uk/1/hi/world/americas/7065061.stm, accessed 20th November 2009

$B B C$ News 2008a, "Call for delay to biofuels policy", 24 ${ }^{\text {th }}$ March, http://news.bbc.co.uk/1/hi/sci/tech/7309099.stm, accessed $7^{\text {th }}$ April 2010

$B B C$ News 2008b, "Brown's biofuels caution welcomed", $22^{\text {nd }}$ April 2008, http://news.bbc.co.uk/1/hi/uk_politics/7359991.stm, accessed $8^{\text {th }}$ April 2010

British Sugar, 2005, "Press Release: UK bioethanol/biofuels campaign launch", http://www.britishsugar.co.uk/IsolatedStorage/94175874-67b5-4c33-9f38380233f14049/ContentAssets/Documents/Bioethanol/Media/MEDIA\%20RELEASE $\% 20150605 \% 20$ Bioethanol\%20v.5.pdf, accessed 20th November 2009

Bulkeley H, 2000, "Discourse coalitions and the Australian climate change policy network" Environment and Planning C 18 727-748

Cohen M D, March J G, Olsen J P, 1972, "A Garbage Can Model of Organizational Choice" Administrative Science Quarterly 17 1-25

Cronon W, 1992, "A Place For Stories: Nature, History and Narrative" Journal of American History 78(4) 1347-1376

Dahl R A, 1957, "The Concept of Power" Behavioural Science 2(3) 201-215

DECC, Department for Energy and Climate Change, 2009 The UK Low Carbon Transition Plan: National Strategy for Climate and Energy (TSO, London)

DEFRA, 2009 The Environment In Your Pocket 2009 (Department for Environment, Food and Rural Affairs, London)

DTI, DfT, DEFRA, 2007 UK Biomass Strategy (Department for Environment, Food and Rural Affairs, London) 
Dickson P, Adams W M, 2009, "Science and uncertainty in South Africa's elephant culling debate" Environment and Planning C: Government and Policy 27(1) 110 - 123

Dunlop C, 2010, "The temporal dimension of knowledge and the limits of policy appraisal: biofuels policy in the UK" Policy Sciences, Advanced Online Pubilcation

EAC, Environmental Audit Committee, 2008a Are Biofuels Sustainable? First Report of the Session 2007-2008, HC 76-1 (TSO, London)

EAC, Environmental Audit Committee, 2008b Are Biofuels Sustainable? First Report of the Session 2007-2008, Oral and Written Evidence, HC 76-2 (TSO, London)

EC, 2003, "Directive 2003/30/EC of the European Parliament and the Council of 8 May 2003 on the promotion of the use of biofuels or other renewable fuels for transport (Biofuels Directive)" Official Journal of the European Union L123 42-46 17th May (European Commission, Brussels)

EC, 2009, "Directive 2009/28/EC of the European Parliament and of the Council of 23rd April 2009 on the promotion and use of energy from renewable sources and amending and subsequently repealing Directives 2001/77/EC and 2003/30/EC (Renewable Energy Directive)" Official Journal of the European Union L140 16-62 15th June (European Commission, Brussels)

EUCAR, CONCAWE, JRC, 2004, "Well-to-wheels Analysis of Future Automotive Fuels and Powertrains in the European Context, Version 1b", http://ies.jrc.ec.europa.eu/uploads/media/WTW_Report_220104.pdf, accessed 20th November 2009

Fargione J, Hill J, Tilman D, Polasky S, Hawthorne P, 2008, "Land Clearing and the Biofuel Carbon Debt" Science 319 1235-1238

Fischer F, 2009 Democracy and Expertise (Oxford University Press, Oxford)

Fischer F, Forester J, 1993 The Argumentative Turn in Policy Analysis and Planning (UCL Press, London)

Fitzpatrick J, 2008, "Biofuels: The Government's Perspective", Keynote speech delivered to London Biofuels Conference, 29th April 2008

Foucault M, 1972 The Archaeology of Knowledge (Routledge, London)

Foucault M, 1978 The History of Sexuality: Volume 1 (Vintage, New York)

Giddens A, 1990 The Consequences of Modernity (Standford University Press, Stanford, CA)

Giddens A, 2009 The Politics of Climate Change (Polity Press, Cambridge)

Gieryn T, 1983, "Boundary-Work and the Demarcation of Science from Non-Science: Strains and Interests in Professional Ideologies of Scientists" American Sociological Review 48 781-795

Greenpeace, 2007, "Biofuels: green dream or climate change nightmare?", http://www.greenpeace.org.uk/blog/climate/biofuels-green-dream-or-climate-changenightmare-20070509, accessed 20th November 2009

Greenpeace, Oxfam, Royal Society for the Protection of Birds, Friends of the Earth, 2008, "Media Brief: Gallager Review to be published early July", http://www.greenpeace.org.uk/files/pdfs/biofuels/GallagherReviewBriefing.pdf, accessed 20th November 2009

Hajer M, 1993, "Discourse Coalitions and the Institutionalisation of Practice: The case of acid rain in Britain", in The Argumentative Turn in Policy Analysis and Planning Eds F Fischer, J Forester (UCL Press, London) pp 43-76

Hajer M, 1995 The Politics of Environmental Discourse (Oxford University Press, Oxford)

Hajer M, Laws D, 2006, "Ordering Through Discourse", in The Oxford Handbook of Public Policy Eds M Moran, M Rein, R E Goodin (Clarendon Press, Oxford) pp 251-268 
Hajer M, Versteeg W, 2005, "A Decade of Discourse Analysis in Environmental Politics: Achievements, Challenges, Perspectives" Journal of Environmental Policy and Planning 7(3) 175-184

Hall P, 1993, "Policy Paradigms, Social Learning and the State" Comparative Politics 25(3) 275-296

Heclo H, 1974 Modern Social Politics in Britain and Sweden (Yale University Press, New Haven, CT)

Hill M, 1997 The Policy Process in the Modern State (Prentice Hall, London)

IEA, International Energy Agency, 2004 Biofuels for Transport: An International Perspective IEA, 9 Rue de la Fédération, 75739 Paris Cedex 15, France

Jasanoff S, 1987, "Contested Boundaries in Policy-Relevant Science" Social Studies of Science 17 195-230

Jasanoff S, 1990 The Fifth Branch: Science Advisers as Policymakers (Harvard University Press, Cambridge, MA)

Jasanoff S, 2004 States of Knowledge: The Co-Production of Science and Social Order (Routledge, London)

Jenkins-Smith H C, Sabatier P, 1993, "The Dynamics of Policy-Oriented Learning", in Policy Change and Learning: An Advocacy Coalition Approach Eds P Sabatier, H C Jenkins-Smith (Westview Press, Boulder, CO) pp 41-56

Keeley J, Scoones I, 1999, "Understanding Environmental Policy Processes: A Review", IDS Working Paper 89, Environment Group, Institute of Development Studies, University of Sussex

Keller A C, 2009 Science in Environmental Policy: The Politics of Objective Advice (MIT Press, Cambridge, MA)

Kingdon J, 2002, "The reality of public policymaking" in Ethical Dimensions of Health Policy Eds M. Danis, C. Clancy and L.R. Churchill (Oxford University Press, Oxford) pp 97-116.

Kingdon J, 2003 Agendas, Alternatives and Public Policies (Longman, New York)

Kirk E, Reeves A, Blackstock K, 2007, "Path dependency and the implementation of environmental regulation" Environment and Planning C: Government and Policy 25(2) $250-268$

Knight F H, 1921 Risk, Uncertainty and Profit (Houghton Mifflin, Boston, MA)

Kuhn T, 1962 The Structure of Scientific Revolutions (University of Chicago Press, London)

Lasswell H, 1956 The Decision Process: Seven Categories of Functional Analysis (University of Maryland, College Park, MD)

Laws D, Rein M, 2003, "Reframing Practice", in Deliberative Policy Analysis: Understanding Governance in the Network Society Eds M Hajer, H Wagenaar (Cambridge University Press, Cambridge) pp 172-206

Lindblom C E, Woodhouse E J, 1993 The Policymaking Process, 3rd Edition (Prentice Hall, Englewood Cliffs, NJ)

Litfin K, 1994 Ozone Discourses: Science and Politics in Global Environmental Cooperation (Columbia University Press, New York)

Lovell H, Bulkeley H, Owens S, 2009, "Converging agendas? Energy and climate change policies in the UK" Environment and Planning C: Government and Policy 27(1) 90 109

Lukes S, 2005 Power: A Radical View, 2nd Edition (Palgrave Macmillan, London) 
Mander S, 2008, "The role of discourse coalitions in planning for renewable energy: a case study of wind-energy deployment" Environment and Planning C: Government and Policy 26(3) $583-600$

Marsh D, Rhodes R A W, 1992, "Policy Communities and Issue Networks: Beyond Typology", in Policy Networks in British Government Eds D Marsh, R A W Rhodes (Oxford University Press, Oxford) pp 249-268

Mol A P J, 2010, "Environmental authorities and biofuels controversies" Environmental Politics 19(1) 61-79

O'Riordan T, Jordan A, 1996, "Social Institutions and Climate Change", in Politics of Climate Change: A European Perspective Eds T O'Riordan, J Jager (Routledge, London)

Owens S, Rayner T, Bina O, 2004, "New agendas for appraisal: reflections on theory, practice and research" Environment and Planning A 36 1943-1959

Parsons, W, 1995 Public Policy: An Introduction to the Theory and Practice of Policy Analysis (Edward Elgar, Aldershot)

Radaelli C, 1995, "The Role of Knowledge in the Policy Process" Journal of European Public Policy 2(2) 159-183

Rein M, Schön D, 1991, "Frame-Reflective Policy Discourse", in Social Sciences and Modern States: National Experiences and Theoretical Crossroads Eds P Wagner, C H Weiss, B Wittrock, H Wollmann (Cambridge University Press, Cambridge) pp 262289

RFA, Renewable Fuels Agency, 2008 The Gallagher Review of the Indirect Effects of Biofuel Production (RFA, East Sussex)

Rittel H, Webber M, 1973, "Dilemmas in a General Theory of Planning” Policy Sciences 4 155-169

Royal Society, 2008 Sustainable Biofuels: Prospects and Challenges (Clyvedon Press, Cardiff)

RSPB, Royal Society for the Protection of Birds, 2008, "A Cool Approach to Biofuels", http://www.rspb.org.uk/Images/Biofuels_tcm9-187450.pdf, accessed 20th November 2009

Sabatier P, 1988, "An Advocacy Coalition Framework of Policy Change and the Role of Policy-Oriented Learning Therein" Policy Sciences 21 129-168

Schattschneider E E, 1960 The Semisovereign People: A Realist's View of Democracy in America (Holt, Reinhart and Winston, New York)

Schmidt V, 2008, "Discursive Institutionalism: The Explanatory Power of Ideas and Discourse" Annual Review of Political Science 11 303-326

Schön D, Rein M, 1994 Frame Reflection: Towards the Resolution of Intractable Policy Controversies (Basic Books, New York)

Searchinger T, Heimlich R, Houghton R A, Dong F, Elobeid A, Fabiosa J, Tokgoz S, Hayes D, Yu T-H, 2008, "Use of U.S. Croplands for Biofuels Increases Greenhouse Gases Through Emissions from Land Use Change" Science 319 1238-1240

Shackley S, Wynne B, 1996, "Representing Uncertainty in Global Climate Change Science and Policy: Boundary-Ordering Devices and Authority" Science, Technology and Human Values 21(3) 275-302

Stevenson R, 2009, "Discourse, power, and energy conflicts: understanding Welsh renewable energy planning policy" Environment and Planning C: Government and Policy 27(3) $512-526$ 
The Guardian 2004, "Brown should stand firm on rising fuel prices", 4th June, http://www.guardian.co.uk/politics/2004/jun/04/economy.oil, accessed 20th November 2009

The Times 2008a, "Rush for biofuels threatens starvation on a global scale", 7th March, http://www.timesonline.co.uk/tol/news/environment/article3500954.ece, accessed 20th November 2009

The Times 2008b, "Interview: Lord Browne of Madingley on biofuels alarmism", 20th October,http://business.timesonline.co.uk/tol/business/industry_sectors/natural_resour ces/article4974872.ece, accessed 20th November 2009

UK Government, 2002 The Renewables Obligation Order 2002 Statutory Instrument 2002 No. 914 (HMSO, London)

UK Government, 2007 The Renewable Transport Fuel Obligations Order 2007 Statutory Instrument 2007 No. 3072 (TSO, London)

van Eeten, M, 1999, “'Dialogues of the deaf' on science in policy controversies" Science and Public Policy 26(3) 185-192

Weinberg A M, 1972, "Science and Trans-Science" Minerva 10 209-222

Weiss C H, 1977, "Research for policy's sake: the enlightenment function of social research" Policy Analysis 3 531-545

Wynne B, Callon M, Goncalves M E, Jasanoff S, Jepsen M, Joly P-B, Konopasek Z, May S, Neubauer C, Rip A, Siune K, Stirling A, Tallacchini M, 2007 Taking European Knowledge Society Seriously Report of the Expert Group on Science and Governance to the Science, Economy and Society Directorate, Directorate-General for Research, European Commission 